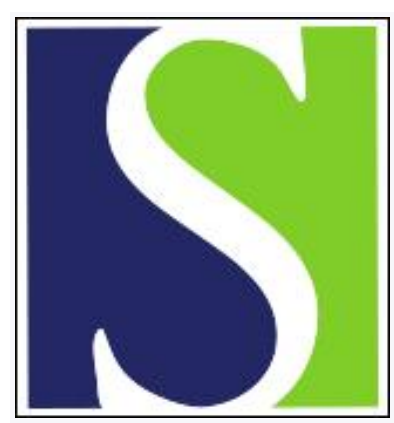

Scand J Work Environ Health 1991;17(3):216-217

https://doi.org/10.5271/sjweh.1717

Issue date: Jun 1991

Disparity between estimated numbers and reported cases of occupational cancer.

by Gaffuri $E$

This article in PubMed: www.ncbi.nlm.nih.gov/pubmed/1829852

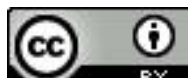


Scand J Work Environ Health 1991;17:216-7

\section{Disparity between estimated numbers and reported cases of occupational cancer}

The recent publication in this journal of an article written by Skov et al ["Reporting of Occupational Cancer in Denmark" (1990;16:401-5)] concerned a problem which probably exists in other countries besides Denmark and undoubtedly in Italy. Certain statements from the aforementioned article may be the case in Italy also when they are altered to fit the Italian circumstances as follows: " . . many patients with an occupational disease fail to obtain compensation because their disease is not reported and compensation is not claimed for. Apparently, this type of situation occurs even for patients with occupational malignancies. ... Reporting of all known and suspected occupational diseases to the [Italian] Labour Inspection Service is compulsory for [Italian] physicians. The report to this service also acts as a claim for worker's compensation from the [National Institute for Work Accidents Insurance - INAIL] [p 401]."

While some occupational diseases, for example, pneumoconioses, have received undue compensation in Italy in proportion to the number of cases confirmed by a group of experts (1), the total number of occupational cancers estimated from epidemiologic research or affirmed by public health institutions differs greatly from the number of occupational cancers reported. This finding is probably not typical of only Italy, as one can see from the data compiled in table 1. Although it is not difficult to obtain the first type of data (epidemiologic estimates) shown in table 1 , it is always difficult or impossible to get information on the second type, even from officials of the European Economic Community.

Knowledge of the actual number, or the most accurate percentage, of cancers caused or linked with occupational factors is not only relevant for the sake of the truth, it would also be useful in clarifying errors in the attribution and extrapolation of epidemiologic estimates (7), in determining the nature of the errors made, in delineating general practitioners' ability to recognize occupational cancer, in determining insurance companies' recognition and attribution of occupational causes, and in revealing any mistakes made by public departments of statistics in the recording of data. Finally, the economic loss of the patients or their relatives is a reality, and it is likely that the lack of occupational cancers in the mortality statistics means a reduction in the disposition towards meeting the costs that the prevention of cancer inevitably entails.

Taking into consideration all the aforementioned possible causes, I believe that the main points are the facts that general practitioners ignore the occupational causes of diseases, namely, cancers, and that they fail to satisfy the obligation of reporting occupational diseases. This opinion is upheld by data on mesothelioma, a type of cancer which has an elevated etiologic specificity with respect to occupational exposure to asbestos. Table 2 shows the six Italian provinces with the highest rates of death from pleural mesothelioma and the corresponding number of men dying from this tumor per year in 1979-1983 (8). In the listed provinces there have been shipyards of various importance, and one of them, the province represented by Alessandria, has been the center of a large industry for cement-asbestos manufacturing. The fact that the cases of occupational cancer reported in Italy in 1988 were probably 22 (table 1) is explicit in itself when related to the data presented in table 2 .

Again, quoting the words of Skov et al, "If this is the state of affairs with well-known occupational cancers like mesothelioma and sinonasal adenocarcinoma, one wonders about cancers which are not as unequivocally associated with occupational exposures (eg, lung cancer, which in crude numbers is the most frequent occupational cancer). How often is an exposure history taken when a lung cancer is diagnosed for a smoker? [p 404]."

These are the questions one asks oneself in Italy when looking at mortality rates from lung cancer, which were (in 1981 per 10000 male residents) 8.5 for

Table 1. Estimated fractions and cases of occupational cancer and the number of reported or compensated cases.

\begin{tabular}{lccccc}
\hline Country & Year & $\begin{array}{c}\text { Refer- } \\
\text { ence }\end{array}$ & $\begin{array}{c}\text { Fraction } \\
\%\end{array}$ & $\begin{array}{c}\text { Estimated } \\
\text { cases } \\
\text { (N) }\end{array}$ & $\begin{array}{c}\text { Reported } \\
\text { or com- } \\
\text { pensated } \\
\text { cases } \\
\text { (N) }\end{array}$ \\
\hline Italy & 1982 & 2 & 2 & 2600 & $22^{\circ}$ \\
France & 1986 & 4 & 4 & 6000 & 101 \\
Germany & 1986 & 5 & $\cdots$ & $\ldots$ & 291 \\
Sweden & 1988 & 6 & 2 & 700 & $\cdots$ \\
\hline
\end{tabular}

a From reference 3 .

Table 2. Pleural mesothelioma mortality in the six Italian districts with the highest death rates (males, 1979-1983, age $35-74$ years)

\begin{tabular}{lcc}
\hline Main town of province & Death rate & Deaths $(N)$ \\
\hline Genova & 12.0 & 31 \\
La Spezia & 11.0 & 6 \\
Trieste & 11.0 & 6 \\
Alessandriab & 8.3 & 10 \\
Taranto & 5.0 & 5 \\
Venezia & 3.5 & 6 \\
\hline
\end{tabular}

a In units of annual deaths per 100000 residents.

- The province was earlier a center for cement-asbestos manufactur. ing. 
northern urbanized and industrialized areas and 6.7 and 5.0, respectively, for central and southern areas, which are less urbanized and industrialized (9).

The fact is that, during a stay in the hospital, it is very unlikely that adequate information is recorded on the occupational exposure of the patient, unless a physician specialized in occupational health is present. Some years ago 73 charts from 68 hospitals were studied (10). There were only six charts containing questions on occupational exposure. In addition the questions were somewhat too vague to guide nonspecialized physicians in their search for a connection between disease and occupation.

It is probably impossible to formulate a short questionnaire that would reveal occupational exposure to a nonspecialized physician in all possible situations, as can be illustrated by the case of a man with pleural mesothelioma. He was reported to have been a laborer in a sugar refinery, while, in fact, he had worked as an asbestos insulator in that factory. However, it could be very useful, although not altogether adequate, to make up a standard chart with suitable space devoted to details on occupational exposure. After the "Blitzkrieg" of the epidemiologist, clinical physicians and general practitioners would then be able to recognize occupationally related deaths and disabilities more accurately than earlier.

\section{References}

1. Gaffuri E, Rubino GF, Chiappino G, Ambrosi L. Epidemiologia e diagnostica delle pneumoconiosi da polveri minerali non fibrose a basso contenuto di silice cristallina. In: Proceedings of the 47th meeting of Italian Society for Occupational Medicine and Industrial Health. Assisi: Italian Society for Occupational Medicine, 1984:255-74.
2. Consiglio Sanitario Nazionale Relazione sullo Stato Sanitario del Paese, 1981/83. Roma, 1987.

3. Mazzella di Bosco M. I tumori professionali alla luce di alcuni recenti contributi. Riv Inf Mal Prof 1989;76: 645-58.

4. Le Galès C, Oudiz A. La prévention des cancerogènes professionnelles: les perspectives ouvertes par l'évaluation des risques et des actions de prévention. Rev Epidemiol Santé Publ 1986;34:387-99.

5. Butz H. Beruflich verursachte Krebserkrankungen: Eine Darstellung der in Zeitraum 1978-1986 bestaetiger Faelle (Translation by G Scansetti). Med Lav 1988;79: 254-6.

6. Hogstedt C. Identification of cancer risk from chemical exposures - an epidemiologic program at the Swedish National Institute of Occupational Health. Scand J Work Environ Health 1988;14(suppl 1):17-20.

7. Veys CA. Towards causal inference in occupational cancer epidemiology - I. an example of the interpretive value of using local rates as the reference statistic. Ann Occup Hyg 1990;34:349-59.

8. Facchini U, Branzaglia P, Marcazzan MG, Camnasio M, Riboldi L, Bertazzi PA. Mortalità per mesotelioma pleurico nel quinquennio $1979-83$ in Italia con riferimento alle Province e singole USSL. Med Lav 1989;80:148-51.

9. Geddes M, Carli S, Farchi G, et al. Mortalità per Tumori nelle Unità Sanitarie Locali 1980/82 Istituto la Ricerca sul Cancro, Genova. Roma: Istituto Superiore di Sanità, 1989.

10. Gaffuri E, Turri P, Maranelli G. Problemi di informazione scientifica in medicina del lavoro (Ricerca sulla struttura delle cartelle cliniche e sul livello di informazione dei medici). Med Lav 1985;76:340—3.

Edoardo Gaffuri, MD

Istituto di Medicina del Lavoro

Università degli Studi di Verona

Policlinico Borgo Roma

I-37134 Verona Italy 